\title{
KLASIFIKASI TINGKAT KEMATANGAN BUAH APEL MANALAGI DENGAN ALGORITMA NAIVE BAYES DAN EKSTRAKSI FITUR CITRA DIGITAL
}

\author{
Antonio Ciputra \\ Program Studi Teknik Informatika, Fakultas Ilmu Komputer \\ Universitas Dian Nuswantoro \\ Email: antoniociputra@gmail.com \\ De Rosal Ignatius Moses Setiadi \\ Program Studi Teknik Informatika, Fakultas Ilmu Komputer \\ Universitas Dian Nuswantoro \\ Email: moses@dsn.dinus.ac.id \\ Eko Hari Rachmawanto \\ Program Studi Teknik Informatika, Fakultas Ilmu Komputer \\ Universitas Dian Nuswantoro \\ Email: eko.hari@dsn.dinus.ac.id \\ Ajib Susanto \\ Program Studi Teknik Informatika, Fakultas Ilmu Komputer \\ Universitas Dian Nuswantoro \\ Email: ajib.susanto@dsn.dinus.ac.id
}

\begin{abstract}
ABSTRAK
Apel merupakan buah yang cukup populer dikonsumsi dan memiliki berbagai jenis bentuk dan warna. Apel sendiri memili berbagai warna kulit, seperti merah, hijau, dan kekuningan. Malang merupakan salah satu pusat budidaya apel di Indonesia. Jenis apel lokal indonesia yang banyak diminati adalah apel manalagi atau lebih sering disebut sebagai apel Malang. Salah satu keunikan apel manalagi adalah warnanya, warna apel ketika mentah dan matang cukup sulit dibedakan karena perbedaanya tidak terlalu siginifikan. Apel yang masih mentah berwarna hijau, sedangkan apel yang sudah matang berwarna hijau kekuningan. Hal ini membuat orang awam cukup sulit untuk membedakannya. Teknologi klasifikasi saat ini dapat dimanfaatkan untuk membatu proses pemilahan tersebut. Penelitian ini mengusulkan metode naive bayes dan ekstraksi fitur citra untuk mengklasifikasi tingkat kematangan buah apel manalagi. Dimana tingkat kematangan akan dibagi menjadi dua jenis, yaitu apel matang dan apel mentah. Ekstraksi fitur yang digunakan pada penelitian ini rerata intensitas, energi, entropy, standar deviasi, smothness dan skewness. Keenam fitur tersebut diklasifikasi dengan naive bayes. Data yang digunakan pada penelittian ini adalah 130 citra, yang terdiri dari 100 citra latih dan 30 citra uji. Hasil akurasi metode ini mencapai $63 \%$.
\end{abstract}

Kata kunci: apel manalagi, naïve bayes, klasifikasi, ekstraksi fitur, citra digital.

\begin{abstract}
Apples are quite popular fruits are consumed and have various types of shapes and colors. Apple itself has a variety of skin colors, such as red, green, and yellowish. Malang is one of the centers of apple cultivation in Indonesia. Types of local apples Indonesia is much in demand is apple manalagi or more often referred to as apple Malang. One of the uniqueness of apple manalagi is the color, the color of apples when raw and cooked quite difficult to distinguish because the difference is not too significant. Apples are still raw green, while ripe apples are yellowish green. This makes the layman quite difficult to distinguish. Current classification technologies can be utilized to facilitate the sorting process. This research proposes naive Bayes method and feature extraction feature to classify maturity level of apple fruit manalagi. Where the maturity level will be divided into two types, namely ripe apples and raw apples. Feature extraction used in this study average intensity, energy, entropy, standard deviation, smoothness and skewness. The six features are classified with Naive Bayes. The data used in this study are 130 images, consisting of 100 training images and 30 test images. Accuracy results of this method reached $63 \%$.
\end{abstract}

Keywords: manalagi apple, nä̈ve bayes, classification, fitur extraction, digital image. 


\section{PENDAHULUAN}

Apel merupakan jenis buah-buahan dimana memiliki beragam jenis warna pada kulitnya tersendiri, ada yang berwarna merah, hijau maupun warna kuning [1]. Nama ilmiah dari apel adalah Malus Domestica. Apel sendiri masuk ke dalam genus yang disebut genus malus. Dimana Genus malus sendiri memiliki pusat keragaman yaitu di Turki Timur. Yang pernah disebutkan bahwa buah apel ini merupakan tanaman pertama dalam dunia pertanian. Kata apel sendiri diambil dari sebuah bahasa inggris kuno yaitu aeppel. Sejak pada jaman besi hingga abad pertama masehi pada masa Romawi telah ditemukan bahwa apel memiliki enam jenis buah apel [1].

Pada dunia pertanian dapat dihasilkan berbagai macam hasil pertanian seperti tanaman hias, buahbuahan, bawang, padi-padian, sayuran, rempah-rempah dan masih banyak lagi. Berdasarkan data yang dirilis oleh direktorat jenderal holtikultura kementrian pertanian tahun 2015 [2], produk pertanian apel memiliki kontribusi yang cukup tinggi di tahun 2014. Hal ini ditunjukan bahwa buah apel di pulau Jawa telah diproduksi sebanyak 242.763 ton dari 249.915 ton produksi di Indonesia. Maka dapat disimpulkan bahwa buah apel menjadi salah satu produk holtikultura yang paling banyak diminati dan dikonsumsi oleh masyarakat, baik dikonsumsi secara langsung maupun yang telah diolah dalam bentuk seperti manisan, keripik, dodol dan minuman.

Buah apel sendiri memiliki banyak nutrisi dan berbagai macam vitamin diantaranya lemak, serta, energi, karbohidrat, protein vitamin C, vitamin A, vitamin B2, vitamin B1 dan masih banyak lagi [3].Di Indonesia yang memiliki pusat budidaya apel terbesar terdapat di daerah Malang, dimana jenis apel yang umum diminati disana adalah jenis buah apel manalagi, rome beauty, dan anna. Dari jenis-jenis buah apel tersebut selain dapat dikonsumsi secara mentah / langsung, maka buah-buahan tersebut dapat dikonsumsi dengan mengolahnya terlebih dahulu yaitu seperti manisan, keripik buah apel dan minuman. Tentunya apabila buah apel ingin diolah maka diperlukan pengetahuan mengenai kematangan buah apel yang cocok untuk diolah sehingga rasa, dan kualitas yang akan diproduksi tetap terjaga dengan baik.

Salah satu jenis apel yaitu apel manalagi, memiliki ciri yang berbeda dari apel-apel lainnya yaitu terdapat pada tingkat warna kematangan buah tersebut. Dimana buah apel manalagi yang masih belum matang memiliki warna hijau dan untuk buah apel manalagi yang sudah matang memiliki warna hijau kekuningan [4]. Hal tersebut tentu akan sedikit menyulitkan untuk membedakan antara buah apel manalagi yang belum matang maupun yang sudah matang apabila tidak terlalu memiliki ilmu mengenai dunia pertanian terutama pada buah apel. Sebab orang awam dirasa akan sulit membedakan. Sehingga akan diperoleh penilaian yang berbeda oleh setiap individu yang menyebabkan tingkat akurasi yang berbeda. Oleh karena itu dibutuhkan suatu teknologi yang dapat menentukan nilai tingkat akurasi dari pengklasifikasian kematangan buah apel manalagi sehingga memperoleh nilai yang konsisten.

Teknologi saat ini memungkinkan untuk melakukan klasifikasi citra digital. Secara umum tahapan dalam proses klasifikasi citra digital yaitu akusisi citra, pra pengolahan citra, ekstrasi ciri/ fitur, pelatihan, pengujian dan pengukuran akurasi. Tahapan mengekstrak ciri atau informasi dalam citra digital sangat mempengaruhi untuk mengenali objek yang ada dalam citra tersebut [5]. Semakin banyak ciri yang diekstrak akan mempengaruhi tingkat akurasi klasifikasi citra. Terdapat bermacam-macam ekstraksi dalam ekstraksi ciri citra yaitu ekstraksi ciri tekstur, bentuk, ukuran, geometri, dan warna [6].

Terdapat algoritma klasifikasi citra yang dapat digunakan dua diantaranya adalah KNN dan Naïve Bayes [7] [8] [9]. Naïve bayes memiliki kesamaan dengan algoritma KNN dalam mengolah jumlah data yang besar akan tetapi Naïve Bayes mengklasifikasikan berdasarkan promentalitas dan teorema bayesian yang mengasumsikan tiap-tiap variabel bersifat bebas sedangan algoritma KNN merupakan metode klasifikasi yang menentukan label (class) dari sebuah objek baru berdasarkan mayoritas class dari jarak terdekat $k$ dalam kelompok data latih [8] [9]. Naïve bayes sendiri adalah dapat menangani kuantitatif dan data diskrit, tidak memerlukan data latih dalam jumlah banyak untuk mengestimasi parameter-parameter yang dibutuhkan untuk klasifikasi, dan cepat dalam melakukan kalkulasi [10]. Oleh sebab itu pada penelitin ini diusulkan klasifikasi kematangan buah apel manalagi berdasarkan ekstrasi fitur citra digital dan Naïve Bayes.

\section{METODOLOGI PENELITIAN}

\subsection{Prapengolahan}

Citra buah apel manalagi yang didapatakan pada penelitian ini memiliki resolusi yang cukup besar sehingga dapat meningkatkan kompleksitas perhitungan. Maka perlu dilakukan resize kedalam ukuran tertentu untuk semua data. Selanjutnya dilakukan proses untuk mentransformasi warna citra dari berwarna (RGB) menjadi keabuan (grayscale), guna inputan untuk proses selanjutnya. Untuk melihat langkah prapengolahan secara lebih detil dapat dilihat pada gambar 1. 


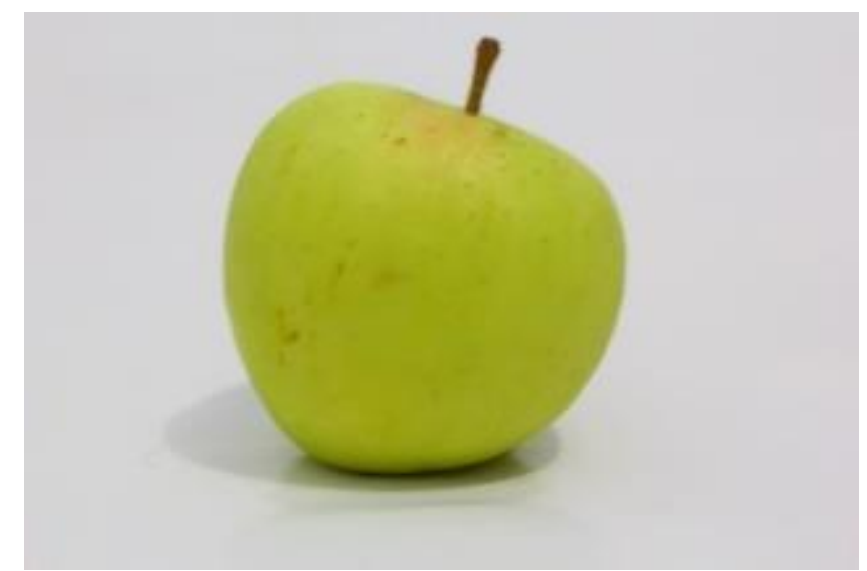

(a)

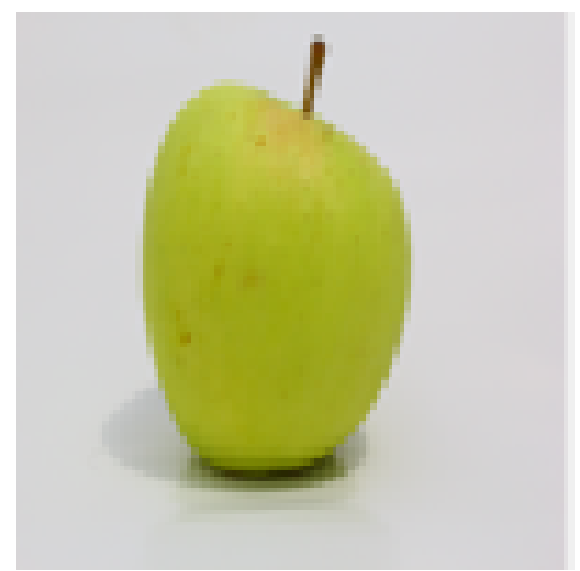

(b)

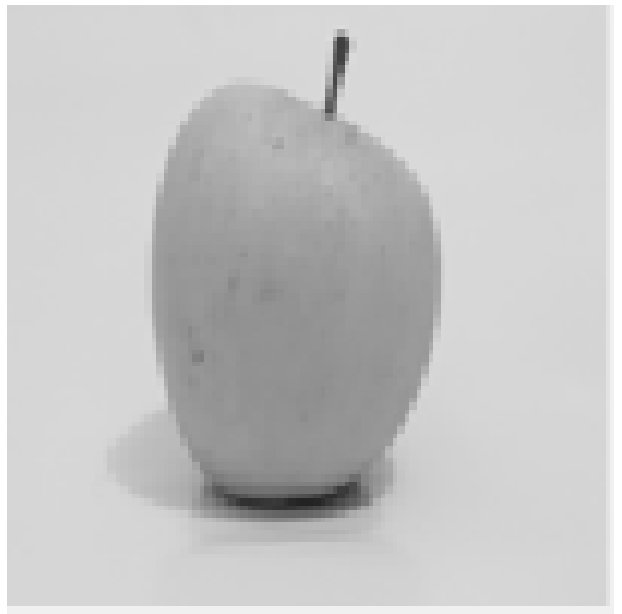

(c)

Gambar 1. Sample Citra Yang Digunakan (a) Citra Asli (b) Citra Sesudah Direzise (c) Citra Setelah Digrayscale

\subsection{Ekstraksi Fitur}

Ekstraksi fitur citra apel manalagi bertujuan untuk memperoleh ciri dari citra apel manalagi mentah dan matang yang menggunakan ekstraksi fitur histogram yang menampilkan hasil berupa numerik. Pada penelitian ini menggunakan enam fitur ekstraksi meliputi: rerata intensitas, energi, entropi, deviasi standar, smothness dan skewness:

\subsubsection{Fitur Rerata Intensitas}

Merupakan fitur untuk mendapatkan histogram dan untuk memberikan informasi tentang penyebaran intensitas nilai pixel. Rerata intensitas dapat dihitung dengan persamaaan (1).

$$
M=\sum_{i=0}^{L-1} i \cdot p(i)
$$




\subsubsection{Fitur Energi}

Fitur energi bertujuan untuk mengetahui intensitas piksel terhadap tingkat keabuan sehingga dapat menggambarkan nilai keseragaman pada sebuah citra. Untuk mendapatkan nilai energy dapat menggunakan persamaan (2).

$$
\text { Energi }=\sum_{i=0}^{L-1}[p(i)]^{2}
$$

\subsubsection{Fitur Entropi}

Fitur ini berguna untuk memebrikan informasi kompleksitas citra digital. Semakin tinggi nilai entropi maka semakin tinggi pula kompleksitas citra tersebut, begitu pula sebaliknya. Untuk mendapatkan fitur energy dapat menggunakan persamaan (3).

$$
\text { Entropi }=\sum_{i=0}^{L-1} p(i) \log _{2}(p(i))
$$

\subsubsection{Fitur Standar Deviasi}

Fitur ini berguna untuk mengetahui tingkat kekontrasan citra. Semakin tinggi kontras citra, maka semakin tinggi pula standar deviasinya, begitu pula sebaliknya. Fitur ini dihitung dengan persamaan (4).

$$
\text { Deviasi }=\sqrt{\sum_{i=0}^{L-1}(i-m)^{2} \cdot p(i)}
$$

\subsubsection{Fitur Skweness}

Fitur ini digunakan untuk mengetahui tingat kesimetrisan citra, atau sering pula disebut momen ordo ketiga. Nilai negatif menunjukan distribusi kecerahan condong kekiri terhadap rerata, sedangkan nilai positif kebalikannya.Nilai fitur ini dihitung dengan persamaan (5).

$$
\text { skew }=\sum_{i=0}^{L-1}(i-m)^{a} \cdot \mathrm{p}(\mathrm{i})
$$

\subsubsection{Fitur Smothness}

Fitur ini untuk mengukur tinggkat kehalusan sebuah citra. Semakin halus citra maka nilai $\mathrm{R}$ akan semkain tinggi, begitu pula sebaliknya. Nilai ini dihitung dengan persamaan (6).

$$
R=1-\frac{1}{1+\text { Deviasi }^{2}}
$$

\subsection{Tahap Klasifikasi}

Setelah nilai-nilai fitur ekstraksi telah didapat. Nilai tersebut akan diklasifikasi dengan Naive Bayes. Klasifikasi dengan Naive Bayes merupakan klasifikasi berdasar teorema Bayes dengan asumsi antar variable penjelas independen. Cara ini dapat diasumsikan sebagai keadaan atau ketiadaan dari sebuah kejadian tertentu dari suatu grup yang tidak berhubungan dengan keadaan atau ketiadaan kejadian lain. Teknik ini dapat dipergunakan untuk berbagai masalah klasifikasi dan dapat diterapkan pada klasifikasi buah apel. Dalam hal ini dikhusukan mengenai penggunaan teorema Naive Bayesian untuk klasifikasi apel manalagi. Secara umum untuk metode Naïve Bayes memiliki metode umum pada persamaan (7). 


$$
p\left(C \mid F 1_{s, \ldots}, F n\right)=\frac{p(C) p\left(F 1_{, \ldots,} F n \mid C\right)}{p\left(F 1_{s, n} F n\right)}
$$

Penggunan metode sebelumnya pada data yang bernilai nominal akan berjalan langsung sebagaimana mestinya. Data yang bernilai numerik memiliki promentahlitas normal atau Gaussian dengan menghitung nilai dari rerata $\mu$ dan standar deviasi $\sigma$ pada setiap class, yang dirumuskan pada persamaan (8).

$$
g(x, \mu, \sigma)=-\frac{1}{\sigma \sqrt{2 \pi}} e^{\frac{-(x-\mu)^{2}}{2\left(\sigma^{2}\right)}}
$$

Dimana pencarian promentahlitas $\mathrm{X}$ berdasarkan kondisi pada hipotesis $\mathrm{Ci}$ pada persamaan (9).

$$
P(X k \mid C i)=g\left(x i, \mu i_{s} \sigma i\right)
$$

\subsection{Tahap Evaluasi}

Penelitian ini menggunakan 130 buah apel manalagi yang terdiri dari 65 apel manalagi matang dan 65 apel manalagi mentah. Tujuan penelitian ini untuk membuktikan berapa presentase keberhasilan pengenalan dengan metode Naïve Bayes dan membandingkan tingkat presentase keberhasilan yang lebih baik antara algoritma naïve bayes dengan algoritma KNN. Untuk menguji tingkat keberhasilan penulis menggunakan perhitungan akurasi confusion matrik. Untuk menghitung accurary digunakan persamaan (10).

$$
\text { Accuracy }=\frac{(a+c)}{(a+b+c+d)} \times 100 \%
$$

\section{HASIL DAN PEMBAHASAN}

Penelitian ini diimplementasikan dengan menggunakan MATLAB, dimana hasil implementasi applikasi dapat dilihat di gambar 2.

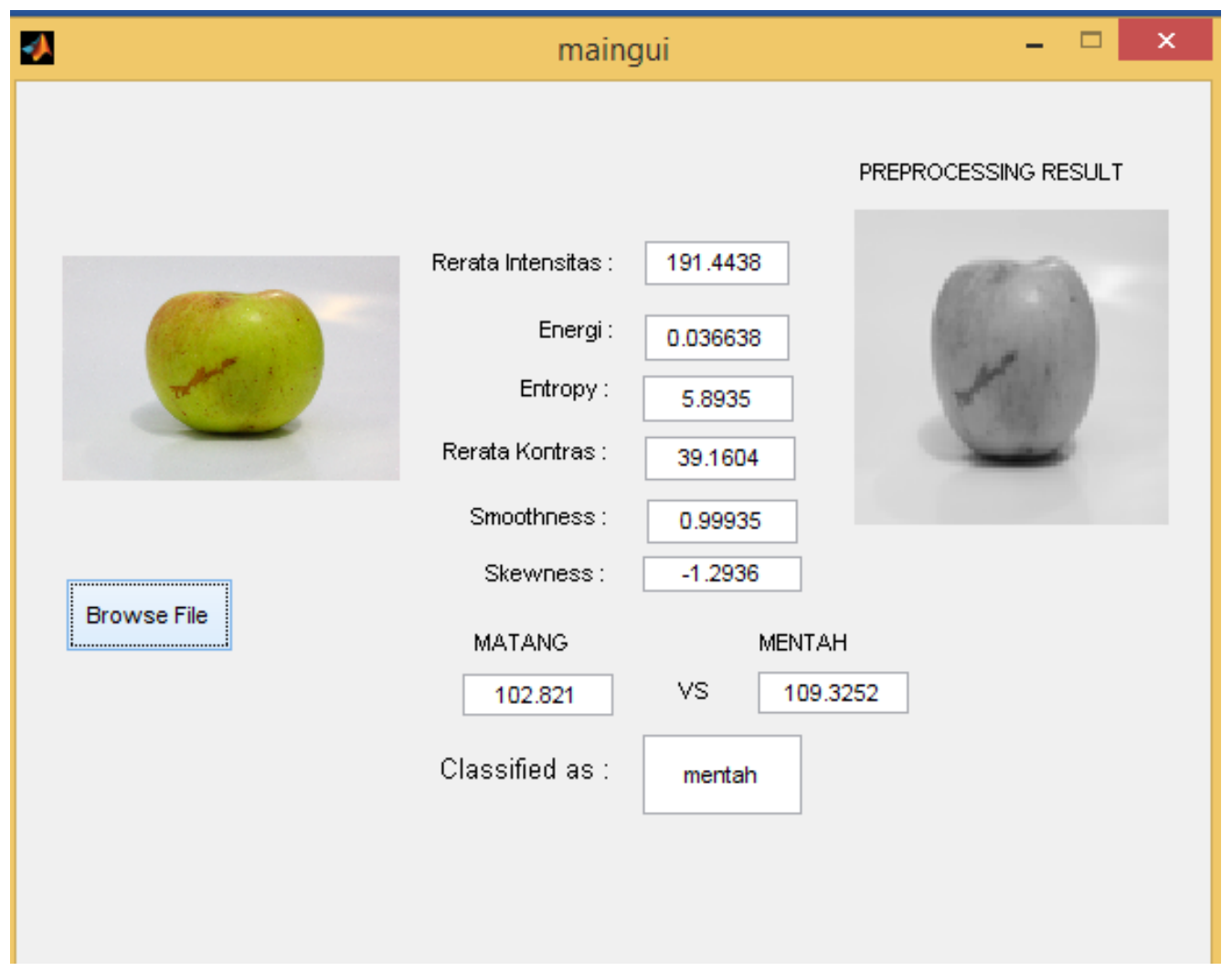

Gambar 2. Aplikasi Klasifikasi Apel Manalagi Berbasis MATLAB 
Berdasarkan gambar 2 dapat dilihat tampilan berbasis Matlab untuk mengklasifikasi tingkat kematangan buah apel manalagi kedalam kategori mentah atau matang berdasarkan ekstraksi citra menggunakan enam atribut yaitu intensitas, energi, entropi, kontras, smotthness, skewness. Berdasarkan rumus intensitas, energi, entropi, kontras, smotthness dan skewness, didapat nilai-nilai yang disajikan pada tabel 1, tabel 2 dan tabel 3. Tabel 1 berisi data ekstraksi fitur untuk citra training matang, Tabel 2 berisi data ektraksi fitur pada citra training mentah, dan tabel 3 berisi hasil ekstraksi fitur pada citra testing.

Tabel 1. Data ekstraksi fitur citra training apel manalagi class matang

\begin{tabular}{ccccccc}
\hline No & Intensitas & Energi & Entopy & Kontras & Smoothness & Skewness \\
\hline 1 & 173,6006 & 0,02813 & 5,955687 & 38,4285 & 0,999323295 & $-1,08492$ \\
2 & 181,4024 & 0,032456 & 6,076351 & 43,68216 & 0,999476201 & $-0,80792$ \\
3 & 173,6006 & 0,02813 & 5,955687 & 38,4285 & 0,999323295 & $-1,08492$ \\
$\cdot$ & $\cdot$ & $\cdot$ & $\cdot$ & $\cdot$ & $\cdot$ & $\cdot$ \\
$\cdot$ & $\cdot$ & $\cdot$ & $\cdot$ & $\cdot$ & $\cdot$ & $\cdot$ \\
$\cdot$ & $\cdot$ & $\cdot$ & $\cdot$ & $\cdot$ & $\cdot$ & $\cdot$ \\
50 & 176,8851 & 0,032033 & 6,137699 & 38,17018 & 0,999314111 & $-0,95811$ \\
\hline
\end{tabular}

Tabel 2. Data ekstraksi fitur citra training apel manalagi class mentah

\begin{tabular}{|c|c|c|c|c|c|c|}
\hline No & Intensitas & Energi & Entopy & Kontras & Smoothness & Skewness \\
\hline 1 & 171,2402 & 0,030987 & 6,198573 & 42,65354 & 0,999450647 & $-0,72855$ \\
\hline 2 & 168,9099 & 0,032635 & 6,131053 & 45,28972 & 0,999512708 & $-0,51836$ \\
\hline 3 & 183,0888 & 0,03546 & 5,755191 & 38,44792 & 0,999323978 & $-1,39871$ \\
\hline . & - & . & . & . & . & . \\
\hline . & . & . & . & . & . & . \\
\hline - & $\cdot$ & $\cdot$ & $\cdot$ & $\cdot$ & $\cdot$ & $\cdot$ \\
\hline 50 & 184,0587 & 0,033777 & 5,774477 & 35,11896 & 0,999189851 & $-1,36781$ \\
\hline
\end{tabular}

Tabel 3. Data ekstraksi fitur citra testing apel manalagi

\begin{tabular}{|c|c|c|c|c|c|c|}
\hline No & Intensitas & Energi & Entopy & Kontras & Smoothness & Skewness \\
\hline 1 & 193,2783 & 0,08269826 & 4,899107718 & 30,21261738 & 0,998905671 & $-39057,68485$ \\
\hline 2 & 165,5362 & 0,0268212 & 5,963052418 & 31,09553167 & 0,99896687 & $-38743,08912$ \\
\hline 3 & 167,5969 & 0,02684752 & 6,088764456 & 35,37498283 & 0,999201526 & $-42289,88659$ \\
\hline . & . & . & . & . & . & . \\
\hline . & . & . & . & . & . & . \\
\hline . & & . & . & . & . & . \\
\hline \multirow[t]{2}{*}{30} & 189,1591 & 0,03386218 & & & & - \\
\hline & & & 5,876822669 & 41,9861428 & 0,999433054 & 70234,10144 \\
\hline
\end{tabular}

Hasil penelitian menggunakan algoritma Naive Bayes tersebut, didapat hasil kecocokan data testing antara data asli citra ujiyang diinputkan dan hasil dari algoritma yang diusulkan dengan menggunakan 30 citra uji tersebut.

Tabel 4. Data ekstraksi fitur citra testing apel manalagi

\begin{tabular}{ccccc}
\hline No & Nama Citra & Target & Hasil & Keterangan \\
\hline 1 & Apell.jpg & Matang & Mentah & Salah \\
2 & Apel2.jpg & Matang & Mentah & Salah \\
3 & Apel3.jpg & Matang & Matang & Benar \\
4 & Apel4.jpg & Matang & Mentah & Salah \\
5 & Apel5.jpg & Matang & Mentah & Salah \\
6 & Apel6.jpg & Matang & Mentah & Salah \\
7 & Apel7.jpg & Matang & Matang & Benar \\
8 & Apel8.jpg & Matang & Matang & Benar \\
9 & Apel9.jpg & Matang & Matang & Benar \\
10 & Apel10.jpg & Matang & Matang & Benar \\
11 & Apel11.jpg & Matang & Matang & Benar \\
12 & Apel12.jpg & Matang & Matang & Benar \\
13 & Apel13.jpg & Matang & Mentah & Salah \\
14 & Apel14.jpg & Matang & Matang & Benar \\
\hline
\end{tabular}




\begin{tabular}{ccccc}
\hline No & Nama Citra & Target & Hasil & Keterangan \\
\hline 15 & Apel15.jpg & Matang & Matang & Benar \\
16 & Apel16.jpg & Mentah & Mentah & Benar \\
17 & Apel17.jpg & Mentah & Mentah & Benar \\
18 & Apel18.jpg & Mentah & Mentah & Benar \\
19 & Apel19.jpg & Mentah & Mentah & Benar \\
20 & Apel20.jpg & Mentah & Mentah & Benar \\
21 & Apel21.jpg & Mentah & Mentah & Benar \\
22 & Apel22.jpg & Mentah & Mentah & Benar \\
23 & Apel23.jpg & Mentah & Matang & Salah \\
24 & Apel24.jpg & Mentah & Mentah & Benar \\
25 & Apel25.jpg & Mentah & Mentah & Benar \\
26 & Apel26.jpg & Mentah & Matang & Salah \\
27 & Apel27.jpg & Mentah & Matang & Salah \\
28 & Apel28.jpg & Mentah & Matang & Salah \\
29 & Apel29.jpg & Mentah & Matang & Salah \\
30 & Apel30.jpg & Mentah & Mentah & Benar \\
\hline
\end{tabular}

Berdasarkan tabel 4, hasil klasifikasi dari 30 buah apel manalagi terdapat 11 kesalahan deteksi dengan menggunakan algoritma Naïve Bayes dan dengan menggunakan rumus (10), maka didapat akurasi hanya sebesar $63 \%$. Hasil penelitian ini masih perlu dikembangkan lagi mengingat akurasi yang relatif masih kurang kurang baik.

\section{KESIMPULAN}

Berdasarkan hasil uji coba yang telah dilakukan pada penelitian ini, terbukti bahwa metode yang diusulkan dapat digunakan untuk mengkalsifikasi apel manalagi. Akan tetapi tingkat akurasi masing kurang memeuaskan, yaitu 63\%. Maka untuk penelitian berikutnya metode dapat dikembangkan lagi. Mungkin dapat dimaksimalkan lagi pada proses prapengolahan dan ekstraksi ciri citra.

\section{DAFTAR PUSTAKA}

[1] Wikipedia, "Apel-Wikipedia," Wikipedia, 26 Agustus 2017. [Online]. Available: https://id.wikipedia.org/wiki/Apel.

[2] Y. Taufik, Statistik Produksi Hortikultura 2014, w. n. d. wahyu widayati, Ed., Jakarta: Direktorat jenderal hortikultura, kementrian pertanian, 2015.

[3] A. R. Cempaka, S. Santoso and L.K.Tanuwijaya, "Pengaruh Metode Pengolahan (Juicing And Blending) Terhadap Kandungan Quercetin Berbagai Varietas Apel Lokal dan Impor," Journal of Human Nutrition, vol. 1, pp. 14-22, 2014.

[4] Sudiyono, January 2012. [Online]. Available: http://widyagama.ac.id/pertanian/wpcontent/uploads/2012/01/6Diono-apel.pdf.

[5] T. Sutojo, P. S. Tirajani, D. R. I. M. Setiadi, C. A. Sari and E. H. Rachmawanto, "CBIR for Classification of Cow Types using GLCM and Color Features Extraction," in International conferences on Information Technology, Information Systems and Electrical Engineering (ICITISEE), Yogyakarta, 2017.

[6] A. Pamungkas, "Ekstraksi Ciri Citra," Pemrograman Matlab, 2015. [Online]. Available: https://pemrogramanmatlab.com/pengolahan-citra-digital/ekstraksi-ciri-citra-digital/. [Accessed Agustus 2017].

[7] A. W. Sukmo, "Identifikasi Kematangan Buah Apel Manalagi Dengan Menggunakan Metode Klasifikasi K-Nearest Neighbhor (KNN)," ePrint UDINUS, Semarang, 2017.

[8] P. D. Wicaksana, "Perbandingan Klasifikasi Knn Dan Naive Bayesian Serta Perbandingan Clustering Simple K-Means Yang Menggunakan Distance Function Manhattan Distance dan Euclidian Distance pada Dataset "Dresses_Attribute_Sales"," Jurnal Teknik Informatika, 2015.

[9] F. S. Ni'mah, T. Sutojo and D. R. I. M. Setiadi, "Identifikasi Tumbuhan Obat Herbal Berdasarkan Citra Daun Menggunakan Algoritma Gray Level Co-occurence Matrix dan K-Nearest Neighbor," Jurnal Teknologi dan Sistem Komputer, vol. 6, no. 2, pp. 51-56, 2018.

[10] O. R. Indriani, E. J. Kusuma, C. A. Sari, E. H. Rachmawanto and D. R. I. M. Setiadi, "Tomatoes Classification Using K-NN Based on GLCM and HSV Color Space," in International Conference on Innovative and Creative Information Technology (ICITECH), Salatiga, 2017. 
[11] D. Jurafsky, "Text Classification and Naïve Bayes," Stanford University, October 2011. [Online]. Available: https://web.stanford.edu/class/cs124/lec/naivebayes.pdf. [Accessed 12 Agustus 2017]. 